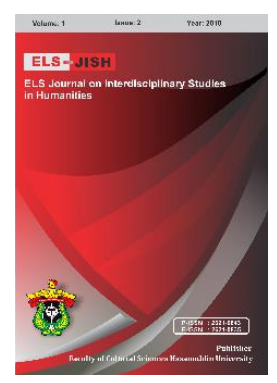

ELS-JISH

ELS Journal on Interdisciplinary Studies on Humanities

Volume 1 Issue 2, 2018

ISSN (print) : 2621-0843

ISSN (online) : 2621-0835

Homepage : http://journal.unhas.ac.id/index.php/jish

\title{
The Influence of Intelligence on Students' Speaking Skills
}

\author{
Wira Kafryawan ${ }^{1}$, Hakim Yassi ${ }^{2}$, Nasmilah ${ }^{3}$ \\ *e-mail of Corresponding Author: wira.kafryawan@gmail.com
}

\begin{abstract}
Intelligence is one of psychological factors which affect the speaking proficiency. Therefore, this study aims at finding out whether or not there is a significant correlation between students' intelligence and their speaking skills. With regard to the methodology applied in this study, a correlation research was used to determine whether, and to what degree, a relationship exists between two or more quantifiable variables in form of quantitative method. Purposive sampling was used in the correlational research due to the assumption that the selected students were able to give information or data in relation to the research problems based on the research design. Thus, 40 students were chosen as the samples. The study was conducted at the first-year students of Senior High School 2 of Makassar. Moreover, the quantifiable data were obtained from speaking test based on the Heaton assessment and intelligence test based on the Barret assessment which were distributed to the students. The data were then analyzed by Pearson product moment. The findings showed that there was a significant correlation between students' intelligence and their speaking skills in degree of high correlation. In other words, the assumption views that the higher intelligence belongs to students the better ability they speak.
\end{abstract}

Keywords: : Intelligence, Speaking Skills, Intelligence Quotient

How to cite: Kafryawan, W; et al. (2018). The Influence of Intelligence on Students' Speaking Skills. ELS Journal on Interdisciplinary Studies in Humanities, 1 (2), 145-152

\section{Introduction}

Speaking is a device to communicate with other people. It is an activity conducted by a person to communicate with others in order to express ideas, feelings, opinions, etc. It is also used to share information among people, to negotiate, to solve problems, to maintain social relationship and friendship. According to Florez \& Cunningham (1999), speaking is the ability which requires the process of communicative competence, pronunciation, intonation, grammar, and vocabulary improvement.

Realizing the importance of English language, Indonesian government considers that English is one of the compulsory subjects to teach. In education, speaking is one of the four basic skills in learning foreign language besides listening, reading, and writing. It has been taught to students from the elementary school to the third year of senior high school. Therefore, it is an essential skill to be learned by students in learning English.

Every student has different perception about speaking. Not all students perceive speaking in the same feeling. Many students judge that speaking is a difficult subject to learn. Moreover, learning how to speak means something different because it deals not only with the efforts of the students to understand the patterns of speaking but also the

\footnotetext{
${ }^{1,2,3}$ Hasanuddin University 
psychological problems inside themselves. In other words, many factors affect students in learning speaking.

There are some psychological factors which influence students in learning speaking. Littlewood (1984), stated that a persons' motivation to learn and the qualities of the opportunities to learn are two of these factors. The third set of factors is those which make up the person's ability to learn. This refers to the intelligence and a set of more specific language learning abilities called 'language aptitude'. Therefore, there are sets of factors which influence how successful a person is to get a good competence in speaking, such as: motivation, interest, environment, or intelligence.

Some previous studies have revealed that motivation is very influential in students' speaking skills. Motivation has high correlation to the students' speaking skills. Likewise, Interest has big influence on students' speaking skills. If students like speaking, they will try to speak more and more. According to Slameto (2003), in learning English, in this case speaking, it is easier for the students if they have high interest. Because it can be made as a tendency to pay attention to and the students can enjoy activities in speaking. However, the problem in some cases that few students who have low motivation and less interest are able to speak English well and vice versa. Environment generally cannot be the best reason of those cases because in Indonesia especially Makassar is not a native-speaker environment. The circumstances completely are not able to support students to stimulate their competence in speaking. Besides, English is rarely used in daily activities to interact with others. Moreover, students are not accustomed to use English neither in the classroom nor outside the classroom. Consequently, intelligence can be the reason that students with low motivation and less interest are able to speak English well and students with high motivation are not.

Some researchers had explored their findings on speaking skills of English as a foreign language and intelligence related to the intelligence quotient. Nurjanah (2011), reported that result of the analysis in her research showed that Interest gives positive influence in teaching-learning speaking skill. Students who have higher interest in speaking get a better score than the lower one. Istianti (2013), revealed that students with higher motivation will get better speaking ability than the lower one. The more motivated students are, the better speaking ability can be achieved. Putri (2015), found in her research that there is a low significance correlation between intelligence quotient and students' learning achievement in English. Intelligence absolutely doesn't influence students' achievement in learning English from her findings.

Psychological factors affecting students' speaking skills are interest and motivation. Intelligence doesn't prove the correlation. The findings above are sufficient to lead the researcher to conduct the research about speaking skill and intelligence as the considerations. Therefore, the sole objective in this paper is to find out whether or not there is a significant correlation between students' intelligence and their speaking skills.

\section{Method}

This part explains about the methodology of the research in specific. Moreover, this study was applied correlational method design in form of quantitative research.

\subsection{Source of Data}

The research was held at Senior High School 2 Makassar. Senior High School 2 of Makassar had been selected as the place of the research because of easy access and 
required data which were suitable to obtain in that place. Correlational research involves collecting data to determine whether, and to what degree, a relationship exists between two or more quantifiable variables. The purpose of correlational research is to establish relationships or use existing relationships to make predictions.

\subsection{Data Collection}

Purposive sampling was used in the correlational research due to the assumption that the selected students were able to give information or data in relation to the research problems based on the research design. Therefore, X.II IPA class was selected as the sample because of limited time and access of the school. The X.II IPA class was sufficient to represent the whole students in first grade. This class consists of 40 students involving 16 males and 24 females.

The data were gathered through intelligence test and speaking test. The first quantifiable data were obtained from intelligence test based on the Barret assessment. The intelligence test consists of five divisions, they are: verbal test, numerical test, perceptual test, spatial test, and practical test. There are 16 criteria of scores on the test. The 16 raw scores were calculated based on right answers. The raw scores were determined by certain scale to get potential score. Finally, to get the mean, the potential scores from all criteria were sum and divided into sixteen. To determine the students' IQ score, the final scores were interpreted based on the table IQ. The second quantifiable data were obtained from speaking test based on the Heaton assessment. It was conducted by oral form to gain the data. Students were given explanation about recount. Then, they were asked to perform their speaking in English in relation to the recount subject. To analyze the data, Students speaking performance was recorded in audio files. The scores were taken in four criteria, which were the scores of grammar, pronunciation, vocabulary, and fluency. Finally, to get the mean, the scores from all criteria were sum and divided into four. To make the speaking scores more objective, inter-rater reliability was used.

\subsection{Data Analysis}

Both quantifiable data were analyzed by Pearson product moment. Scores within a certain range on first variable are associated with scores within a certain range on the second variable. The Pearson product moment was engaged in the analysis of data between scores of students' intelligence and scores of their speaking skills. It is used to find out the significance of existing relationship.

$$
\begin{gathered}
r=\frac{\sum X Y-\frac{\left(\sum X\right)\left(\sum Y\right)}{N}}{\sqrt{\left[\sum X^{2}-\frac{\left(\sum X\right)^{2}}{N}\right]\left[\sum Y^{2}-\frac{\left(\sum Y\right)^{2}}{N}\right]}} \\
r \quad=\text { correlational coefficient } \\
N \quad=\text { number of respondents } \\
X \quad=\text { distribution of students' intelligence } \\
Y \quad=\text { distribution of students' speaking skills }
\end{gathered}
$$

(Gay et al., 2006) 


$$
\begin{array}{ll}
\sum X & =\text { total score of students' intelligence } \\
\sum Y & =\text { total score of students' speaking skills } \\
\sum X^{2} & =\text { the sum of the square from Variable } \mathrm{X} \\
\sum Y^{2} & =\text { the sum of the square from Variable } \mathrm{Y} \\
\sum X Y & =\text { total number of } \mathrm{X} \text { multiplied by } \mathrm{Y}
\end{array}
$$

\section{Findings}

The findings in this research refer to analysis and description of the data based on the certain instruments which are used. Both data of the students' intelligence and data of their speaking skills were correlated by using Pearson Product Moment. After being calculated by using Person product moment formula, Result of the calculation in Table 1 elaborated that $N(40), \Sigma X(2436), \Sigma Y(2585), \Sigma X^{2}$ (152898), $\Sigma Y^{2}$ (170591), $\Sigma X Y(160452)$. Finally, it was found out that the correlation coefficient $\left(r_{0}\right)$ is 0.75 .

Table 1. Data of the Correlation between Intelligence and Speaking Skills

\begin{tabular}{cccccc}
\hline No. & $\mathbf{X}$ & $\mathbf{Y}$ & $\mathbf{X}^{\mathbf{2}}$ & $\mathbf{Y}^{\mathbf{2}}$ & $\mathbf{X Y}$ \\
\hline $\mathbf{1}$ & 52 & 67 & 2704 & 4489 & 3484 \\
$\mathbf{2}$ & 65 & 65 & 4225 & 4225 & 4225 \\
$\mathbf{3}$ & 50 & 63 & 2500 & 3969 & 3150 \\
$\mathbf{4}$ & 58 & 62 & 3364 & 3844 & 3596 \\
$\mathbf{5}$ & 63 & 54 & 3969 & 2916 & 3402 \\
$\mathbf{6}$ & 59 & 58 & 3481 & 3364 & 3422 \\
$\mathbf{7}$ & 58 & 61 & 3364 & 3721 & 3538 \\
$\mathbf{8}$ & 72 & 82 & 5184 & 6724 & 5904 \\
$\mathbf{9}$ & 51 & 55 & 2601 & 3025 & 2805 \\
$\mathbf{1 0}$ & 53 & 60 & 2809 & 3600 & 3180 \\
$\mathbf{1 1}$ & 73 & 71 & 5329 & 5041 & 5183 \\
$\mathbf{1 2}$ & 54 & 55 & 2916 & 3025 & 2970 \\
$\mathbf{1 3}$ & 67 & 66 & 4489 & 4356 & 4422 \\
$\mathbf{1 4}$ & 64 & 72 & 4096 & 5184 & 4608 \\
$\mathbf{1 5}$ & 59 & 65 & 3481 & 4225 & 3835 \\
$\mathbf{1 6}$ & 75 & 66 & 5625 & 4356 & 4950 \\
$\mathbf{1 7}$ & 61 & 55 & 3721 & 3025 & 3355 \\
$\mathbf{1 8}$ & 61 & 62 & 3721 & 3844 & 3782 \\
$\mathbf{1 9}$ & 69 & 67 & 4761 & 4489 & 4623 \\
$\mathbf{2 0}$ & 69 & 69 & 4761 & 4761 & 4761 \\
$\mathbf{2 1}$ & 46 & 59 & 2116 & 3481 & 2714 \\
$\mathbf{2 2}$ & 59 & 63 & 3481 & 3969 & 3717 \\
$\mathbf{2 3}$ & 64 & 65 & 4096 & 4225 & 4160 \\
$\mathbf{2 4}$ & 62 & 69 & 3844 & 4761 & 4278 \\
$\mathbf{2 5}$ & 74 & 72 & 5476 & 5184 & 5328 \\
$\mathbf{2 6}$ & 72 & 67 & 5184 & 4489 & 4824 \\
$\mathbf{2 7}$ & 19 & 37 & 361 & 1369 & 703 \\
$\mathbf{2 8}$ & 62 & 63 & 3844 & 3969 & 3906 \\
$\mathbf{2 9}$ & 61 & 60 & 3721 & 3600 & 3660 \\
$\mathbf{3 0}$ & 51 & 57 & 2601 & 3249 & 2907 \\
$\mathbf{3 1}$ & 68 & 78 & 4624 & 6084 & 5304 \\
$\mathbf{3 2}$ & 76 & 76 & 5776 & 5776 & 5776 \\
$\mathbf{3 3}$ & 49 & 53 & 2401 & 2809 & 2597
\end{tabular}




\begin{tabular}{cccccc}
$\mathbf{3 4}$ & 62 & 88 & 3844 & 7744 & 5456 \\
$\mathbf{3 5}$ & 59 & 62 & 3481 & 3844 & 3658 \\
$\mathbf{3 6}$ & 59 & 62 & 3481 & 3844 & 3658 \\
$\mathbf{3 7}$ & 80 & 85 & 6400 & 7225 & 6800 \\
$\mathbf{3 8}$ & 56 & 71 & 3136 & 5041 & 3976 \\
$\mathbf{3 9}$ & 51 & 52 & 2601 & 2704 & 2652 \\
$\mathbf{4 0}$ & 73 & 71 & 5329 & 5041 & 5183 \\
$\mathbf{N =}$ & $\sum \mathbf{X}$ & $\sum \mathbf{Y}$ & $\sum \mathbf{X}^{\mathbf{2}}$ & $\sum \mathbf{Y}^{2}$ & $\sum \mathbf{X Y}$ \\
$\mathbf{4 0}$ & $\mathbf{2 4 3 6}$ & $\mathbf{2 5 8 5}$ & $\mathbf{1 5 2 8 9 8}$ & $\mathbf{1 7 0 5 9 1}$ & $\mathbf{1 6 0 4 5 2}$ \\
\hline
\end{tabular}

From the explanation above, it can be seen that the correlation index $\left(r_{0}=0.75\right)$ is in the interval of $0.70-0.90$, this means that the correlation belongs to "high correlation". In other words, there is a significance correlation in the degree of high correlation between variable $X$, intelligence and variable $Y$, speaking skills. To attest and prove the result of data calculation, Degree of Freedom and its significant critical value was used. As mentioned before, from the result of calculation, the value of $r o$ is 0.75 ; $d f$ is 38 . If it was compared with the $r t$ at the degree of significance $5 \%(0.3044)$ and $1 \%(0.3932)$, the correlation between students' intelligence and their speaking skills is significant based on the hypothesis $(r o: r t=0.75>0.3044 ; r o: r t=0.75>0.3932)$. So, the null hypothesis $(\mathrm{Ho})$ of the research is rejected and alternative hypothesis $(\mathrm{H \alpha})$ is accepted. The meaning of this statement is that there is a significance correlation between students' intelligence and their speaking skills.

\section{Discussion}

In this research, the writer had found out that there is an existing relationship between students' intelligence and their speaking skills. Concerning to the definition, Sternberg in Marwaha (2015), termed Intelligence as a mental capacity which entails recognition and alteration of the surroundings in which an individual life. The level of IQ had been a predictor of the level of academic achievement of students. Intelligence will encourage academic success and promote a quality learning experience (Saibani \& Simin, 2015). Intelligence is the ability to engage in various forms of reasoning, to understand complex ideas, to learn from experience, to adapt effectively to the environment and to overcome obstacles, a report by American Psychological Association 'Intelligence: Known and Unknown' :1995, (Muley, 2014). Moreover, According to Florez \& Cunningham (1999), speaking is the ability that requires the process of communicative competence, pronunciation, intonation, grammar, and vocabulary improvement.

Concerning to the internal factors of intelligence itself, further elaboration is viewed. Specifically, there are elements of intelligence which can be presupposed to influence the development of speaking competence. It consists of actuators, sensors, sensory processing, world model, value judgment, and behavior generation. Nevertheless, not all of the elements have significant role in speaking competence.

First, actuators mean that output from an intelligent system is produced by actuators that move, exert forces, and position arms, legs, hands, and eyes (Albus, 1991). Concerning to the speaking skills, the ideas put forward the view that actuators have significant influence on speaking skills development because actuators work on sustaining the output when someone produces sounds, words, and sentences in speaking particularly when conversation occurs. Second, sensors mean that input to an intelligent system is produced by sensors, which may include visual brightness and color sensors; tactile, force, vibration, acoustic, range, smell, taste, pressure, and temperature (Albus, 1991). Related 
to the speaking, the view seems to be that sensors are significantly influencing on speaking skills development because sensors stimulate the input signal and forward it to the next sensory processing. Third, sensory processing integrates similarities and differences between observations and expectations over time and space so as to detect events and recognize features, objects, and relationships in the world. Sensory processing may include recognition of speech and interpretation of language and music (Albus, 1991). Therefore, sensory processing is very influential on speaking skills development. Fourth, the world model includes a database of knowledge about the world, plus a database management system that stores and retrieves information (Albus, 1991). Concerning to the speaking skills, the ideas put forward the view that world model is very important in maintaining the vocabulary database. In other words, world model related to the vocabulary database pointedly enhance the speaking competence. Fifth, the value judgment system element determines what is good and bad, rewarding and punishing, important and trivial, certain and improbable (Albus, 1991). Related to the speaking competence, the view seems to be that value judgment is not absolutely significant influencing on speaking skills development because the judgment content both goodness and evilness has no relation with speaking skills. Sixth, behavior generation means that behavior results from a behavior generating system element that selects goals, and plans and executes tasks (Albus, 1991). In other words, it is a decision maker. Based on the explanation, there is no relationship between behavior generation and speaking skills development.

Therefore, several elements of intelligence are very essential in development of speaking competence, especially actuators concerning to the output, sensors related to the input, sensory processing, and world model. Those elements contain sustenance to gain the competence in speaking. However, there are few elements which are not dominant on development of speaking competence. It is assumed that value judgment and behavior generation have no role in speaking competence. The explanation above can be advanced to support the finding that some elements inside of intelligence affect the significance of the mutual relationship between students' intelligence and their speaking skills.

In further overview, the mutual relationship between intelligence and speaking competence can be reinforced by other external psychological factors beyond intelligence itself, such as the influence of motivation, interest, environment, and gender. An occurrence of intercorrelation can't be denied. A mutual relationship between more than two variables can happen.

First, motivation as an external factor which interfere the significant relationship between intelligence and speaking skills. Motivation involves the processes that energize, direct, and sustain behavior (Santrock, 2006). I develop the argument that the higher motivation belongs to students the more significant relationship between students' intelligence and their speaking skills. Second, interest is also an external factor which affects how significant the relationship between intelligence and speaking skills is. According to Hurlock (1987), interests are sources of motivation which drive people to do what they want to do when they are free to choose. Interest can increase both students' intelligence and their speaking competence because it can be made as a tendency to pay attention to, like, and love. So, I put forward the idea that the higher interest belongs to students the more significant relationship between students' intelligence and their speaking skills. 
Third, as an external factor, social environment has important role to determine the significant relationship between intelligence and speaking skills. Social environment can be viewed as tension systems consisting of forces in a dynamic state of interaction that remains relatively stable over time (Ross \& Nisbett, 1991). I propound the view that the better environment belongs to students the more significant relationship between students' intelligence and their speaking skills. Fourth, Gender seems to have effect also to determine the significant relationship between intelligence and speaking skills. Gender is one of the personal variables that have been related to differences found in motivational functioning and in self-regulated learning (Burgner \& Hewstone in Ghazvini \& Milad, 2011). However, a closer look at the data indicates that 59\% girls excel in speaking competence and $58 \%$ girls excel in intelligence capacity. My findings lend support to claim that girls are more dominant than boys concerning to the speaking competence and intelligence. Thus, I put forward the assumption that gender influence the significant relationship between students' intelligence and their speaking skills.

Based on the explanation above, not only inside of intelligence but external factors beyond intelligence affect the relationship between intelligence and speaking competence particularly the influence of motivation, interest, environment, and gender. Those factors have great impact to both development of speaking skills and development of intelligence. So, there is ample support for the finding that external factors beyond intelligence affect the significance of the mutual relationship between students' intelligence and their speaking skills.

The foregoing discussion implies that there is a significant correlation between students' intelligence and their speaking skills influenced by the elements inside of intelligence and external factors. It can be seen in findings that the correlation index ( $r o=$ 0.75 ) is in the interval of $0.70-0.90$, this means that the correlation belongs to high correlation. Therefore, the data supported by some arguments and yielded by the findings provide strong evidence that the higher intelligence belongs to students the better ability they speak.

\section{Conclusion}

There is a significant correlation between students' intelligence and their speaking skills at the first-year students of Senior High School 2 of Makassar, where correlation coefficient belongs to high correlation. In other words, the assumption views that the higher intelligence belongs to students the better ability they speak. Therefore, the teachers should pay attention more about students' intelligence due to the fact that it has vital roles in improving students' speaking skills. Also, Intelligence test should be given to the whole students to assess their intelligence.

\section{References}

Albus J.S. (1991). Outline for a Theory of Intelligence. USA: IEEE Transactions on Systems.

Florez \& Cunningham M. (1999). Improving Adult English language Learners' Speaking Skills. Accessed at $25^{\text {th }}$ December 2016. Available from: http://www.ericdigests.org/2000-3/adult.htm.

Gay L.R. et al. (2006). Educational Research. New Jersey: Pearson Education, Inc. 
Ghazvini S.D. \& Milad K. (2011). Gender Differences in Factors Affecting Academic Performance of High School Students. International Journal of Social and Behavioral Science, Vol. 15, 1040-1045. Available online at www.sciencedirect.com.

Hurlock E.B. (1987). Child Development. Singapore: Mc. Graw-Hill Book Company.

Istianti N. (2013). The Correlation between Students' Motivation in Learning Speaking and Their Speaking Ability: A Correlational Study in the Second Grade of SMA Darussalam Ciputat (Thesis). Jakarta: Syarif Hidayatullah State Islamic University.

Littlewood W.T. (1984). Foreign and Second Language Learning. Cambridge: Cambridge University Press.

Marwaha S. (2015). Analysis of Emotional Quotient and Intelligence Quotient among 'High Achievers' and 'Low Performers' in School Academics. International Journal of Home Science, 1(2): 26-31.

Muley D.V. (2014). Psychology: Semester 1 \& 2. Kolhapur: Shivaji University Press.

Nurjanah N. (2011). The Relationship between Students' Interest in Speaking and Their Speaking Score: A Correlational Study at the Second Grade of MTsN Parung (Thesis). Jakarta: Syarif Hidayatullah State Islamic University.

Putri R.A. (2015). The Correlation between Intelligence Quotient and Students' Achievement in Learning English at the First-Year Students of SMPIT Nurul Fikri Depok (Thesis). Jakarta: Syarif Hidayatullah State Islamic University.

Ross L. \& Nisbett R.E. (1991). The Person and the Situation. New York: McGraw-Hill.

Saibani B. \& Simin S. (2015). The Relationship between Multiple Intelligence and Speaking Skill among Intermediate EFL Learners in Bandar Abbaz University in Iran. International Journal of Research Studies in Language Learning, 4(2): 43-56.

Santrock J.W. (2006). Educational Psychology. New York: Te McGraw-Hill Companies.

Slameto. (2003). Belajar dan Faktor-Faktor yang Mempengaruhinya. Jakarta: Rineka Cipta. 